\title{
KRIMINĀLPROCESUĀLA, CIVILPROCESUĀLA VAI ADMINISTRATİVI PROCESUĀLA KONFISKĀCIJA
}

\section{CONFISCATION OR FORFEITURE IN CRIMINAL, CIVIL OR ADMINISTRATIVE PROCEEDINGS}

\author{
Gunārs Kūtris, Mg. iur. \\ Latvijas Universitātes Juridiskās fakultātes \\ Krimināltiesisko zinātṇu katedras lektors
}

\begin{abstract}
Summary
The confiscation or forfeiture of crime proceeds is an important challenge in the fight against crime in every country. The Latvian Criminal Procedure Law (2005) provides ability of confiscating criminally acquired property before the sentencing of the guilty person, as well as the ability to apply extended confiscation for a convicted person. However, in recent years, practices and amendments to the law show trends that raise doubts about respect for human rights and principles of criminal proceedings in confiscation processes. The article deals with other countries' experience in the confiscation of property of uncertain origin in various processes - administrative, civil and criminal proceedings. The summary gives the author's conclusions on the legally correct confiscation process.
\end{abstract}

Atslēgvārdi: noziedzīgi iegūta manta, konfiskācija, process.

Keywords: crime proceeds, confiscation, forfeiture, proceeding.

[1] Neviens nav jāpārliecina par nepieciešamību izṇemt no noziedznieku rokām (valdījuma, turējuma, rīcības utt.) noziedzīgi iegūtu mantu vai piedzìt šis mantas vêrtību. Šì jautājuma aktualitāte pēdējos gados vairāk saistîta ar koruptīvajiem noziegumiem un noziedzīgi iegūtā legalizāciju. Saistībā ar to praksē dažkārt kḷūst neskaidrs jautājums par to, kas īsti ir noziedzīgi iegūtā manta. Protams, par šādas mantas klasisko izpratni diskusiju nav, jo to precizi nosaka Krimināllikuma ${ }^{1} 70 .{ }^{11}$ panta pirmā daḷa. Taču izrādās, ka manta par noziedzīgu tiek atzìta arī pēc citiem kritērijiem, "papildus Krimināllikumā noteiktajam". Piemēram, Noziedzīgi iegūtu līdzekḷu legalizācijas un terorisma un proliferācijas finansēšanas novēršanas likuma ${ }^{2}$ 4. panta trešās dal̦as 2. punkts (analogi ir arī pārējie punkti) par noziedzīgiem l̦auj atzìt līdzekḷus, kas pieder personai, "kura ir iekḷauta uz Starptautisko

\footnotetext{
1 Turpmāk tekstā - KL.

2 Turpmāk tekstā - Legalizācijas novēršanas likums.
} 
un Latvijas Republikas nacionālo sankciju likuma pamata Ministru kabineta sastādītājā sankciju subjektu sarakstā nolūkā cīnīties pret iesaistīšanos teroristiskās darbībās vai masveida iznīcināšanas ieroču izgatavošanā, glabāšanā, pārvietošanā, lietošanā un izplatīšanā”. Nav saprotams, kas pierāda šo personu noziedzīgo darbību un kādā procesā personas manta tiek atzīta par noziedzīgu.

Tāpat arī "prezumētā noziedzīgi iegūtā manta" un "paplašinātā konfiskācija" prasa dziḷākus pētījumus. It ìpaši tādos apstākḷos, kad vērojama tendence par noziedzīgi iegūtu atzìt jebkurai personai piederošu mantu, ja vien tā nespēj izskaidrot mantas izcelsmi. Proti, tendence par noziedzīgu atzìt arī to mantu, kuras legālā izcelsme nav noskaidrota tiesiski korektā procesā.

[2] Lai gan Direktīvas 2014/42/ES par nozieguma rīku un noziedzīgi iegūtu līdzekḷu iesaldēšanu un konfiskāciju Eiropas Savienībā 2. pantā tiek definēts, ka "konfiskācija" ir īpašuma galīga atṇemšana, ko tiesa norīkojusi saistībā ar noziedzīgu nodarījumu, varam redzēt, ka Latvijas praksē ir mēginājumi konfiskāciju attiecināt ne tikai uz noziedzīgi iegūtu mantu, bet uz jebkuru neskaidras izcelsmes īpašumu. Iespējams, tāpēc citās valstīs līdzīgās situācijās piesardzīgi lieto vārdu "konfiskācija" (confiscation), to aizstājot ar jēdzienu "atsavināšana" (forfeiture), bet tas gan nemaina mantas atsavināšanas būtỉbu.

[3] Līdz ar to ir svarīgi tieši no procesuālā viedokḷa izvērtēt, kas un kam jāpierāda, lai valsts būtu tiesīga atzìt mantu par noziedzīgi iegūtu un to konfiscēt, kā procesuālie principi ietekmē šo pierādīšanas pienākumu, visbeidzot, kādā procedūrā būtu vispareizāk šo jautājumu izlemt. No vienas puses, ja jau runāts tiek par noziedzīgi iegūtu mantu, tad šis risinājums šķiet tuvāks kriminālprocesam. Pirmkārt, jau noziedzīgi iegūtas mantas definējums ir sniegts Krimināllikumā. Otrkārt, Kriminālprocesa likumā $\bar{a}^{3}$ ir norādīti vairāki procesuālie risinājumi, kā mantu var atzìt par noziedzīgi iegūtu.

Tomēr pēdējos gados juristu darbos un starptautiskajos dokumentos parādās idejas par noziedzīgi iegūtā konfiskācijas iespējām gan administratīvā procesa kārtībā, gan civilprocesā. Pat Eiropas Cilvēktiesību tiesa ${ }^{4}$ ir atzinusi par labu esam konfiskāciju civilprocesa kārtībā' $\overline{5}^{5}$ Tāpēc būtu interesanti izvērtēt šīs iespējas un atrast veiksmīgāko risinājumu. Papildu uzmanību rada arī tas, ka gandrīz nevienas valsts kriminālprocesu likumos nav paredzēta iespēja, kā mantu varētu atzìt par noziedzīgu, pirms pati persona vēl nav notiesāta (t. s. non-convicted situācijas). Tāda konfiskācija parasti notiek civilprocesa kārtībā.

[4] Vai Latvija būtu pasteigusies? Varbūt KPL labi domātais sevišķais process par noziedzīgi iegūtu mantu tiek izmantots nesamērīgi plaši, proti, arī tādās situācijās, kad tiek pārkāptas cilvēktiesības un process vairs neatbilst taisnīgas tiesas procesam? Iespējams, ir jāatkāpjas un katram jāierāda sava vieta. Aplūkosim dažādas versijas un citu pieredzi.

\section{Konfiskācijas iespējas administratīvā procesa kārtībā}

[5] Dažās Austrumu valstīs iespējama mantas konfiskācija saistībā ar administratīvo pārkāpumu, taču pamatā šì administratīvā procesa iespējamība saistīta ar

\footnotetext{
3 Turpmāk tekstā - KPL.

4 Turpmāk tekstā - ECT.

${ }^{5}$ Sk. ECT 12.05.2015. spriedumu lietā Gogitidzeandothers v. Georgia (pieteikums Nr. 36862/05).
} 
juridisko personu atbildību (teorija neatzīst šo personu krimināltiesisko atbildìbu). Šāds risinājums nebūtu analizējams krimināltiesiskās konfiskācijas aspektā.

[6] Kādā OECD 2018. gada pētījumā̄ Igaunija pieminēta kā valsts, kur iespējama noziedzīgi iegūtā konfiskācija administratīvā procesa kārtībā. Teorētiski tam varētu piekrist. Taču šì administratīvā "atsavināšana”, kā to regulē Naudas atmazgāšanas un terorisma finansēšanas novēršanas likuma ${ }^{7}$ (līdzìgs Latvijas Legalizācijas novēršanas likumam) 57. panta septītā daḷa, paredzēta gadijumiem, kad Finanšu izlūkošanas vienība ir iesaldējusi kādus līdzekḷus kā iespējami noziedzīgi iegūtus un gada laikā nav noskaidrots īpašnieks (neviens nav vērsies prokuratūrā vai administratīvajā tiesā), proti, gada laikā nav identificēts ìpašnieks. Tad pēc Finanšu izlūkošanas vienības iesnieguma administratīvā tiesa dod atḷauju attiecīgos aktīvus vai īpašumu ieskaitīt valsts īpašumā. Savukārt ìpašniekam, ja tāds uzrodas, ir iespēja 3 gadu laikā prasīt atlīdzinājumu. Kā savos gada pārskatos informē Finanšu izlūkošanas vienība, piemēram, 2017. gadā tā šādu prasījumu iesniedza tiesai 3 reizes, vienā gadỉjumā tika atteikts. ${ }^{8}$

[7] Konfiskācijai tuvāka ir mantas atsavināšana Rumānijā. 2010. gada 1. septembra likums "Par integritātes aǵentūru" (pēc būtības - interešu konflikta un korupcijas novēršanas dienests) paredz, ka ir iespējama īpašuma administrativa atsavināšana lietās, ko izmeklē šì aǵentūra ${ }^{9}$. Ja aǵentūra konstatē, ka personas īpašuma vērtība būtiski (virs 10000 EUR) pārsniedz oficiālos ienākumus, tā var griezties tiesā ar lūgumu konfiscēt (seizure) nepamatoti gūto. ${ }^{10}$ Šajā procesā ienākumi netiek vērtēti kā noziedzīgi iegūti.

[8] Administratīvā konfiskācija Bulgārijā pēc būtības ir neliels sajaukums ar civilprocesuālo. Atsavināšana (forfeiture) paredzēta 2012. gada oktobrī pieņemtajā Nelegālo aktīvu atsavināšanas likumā. ${ }^{11}$ Procedūra nav saistīta ar kriminālprocesu, tā nav pret personu, bet pret îpašumu. Nelegālo aktīvu atsavināšanas komisija (CIAF) uzsāk administratīvu procedūru, lai pārbaudītu neskaidras izcelsmes ienākumus, ja personas ienākumi nesakrīt ar aktīviem (apmēram virs 125000 EUR). Pārbaudes uzsākšanai iemesls var būt arī noziegums (likuma 22. pantā dots izsmel̦ošs uzskaitījums) vai administratīvs pārkāpums (gūtais labums pārsniedz apmēram 75000 EUR). Tomēr, ja pārbaudes iemesls ir noziegums, pārbaude nevar sākties, pirms nav uzrādīta apsūdzība vai ja kriminālprocesu pret konkrētu personu nevar virzìt tālāk (amnestija, noilgums, nāve, persona meklēšanā). Pēc pārbaudes pabeigšanas komisija iesniedz civiltiesā prasību par nelikumīgo ienākumu

${ }^{6}$ OECD (2018). Confiscation of instrumentalities and proceeds of corruption crimes in Eastern Europe and Central Asia. Pieejams: https:/www.oecd.org/corruption/acn/OECD-Confiscation-of-Proceedsof-Corruption-Crimes-ENG.pdf [aplūkots 05.03.2021.].

7 Money Laundering and Terrosist Financing Prevention Act. Igaunijas Republikas likums. Pienemts 26.10.2017. Pieejams: https://www.riigiteataja.ee/en/eli/517112017003/consolide [aplūkots 05.03.2021.].

8 Overview of the work of the Financial intelligence unit in 2017. Pieejams: https://www.politsei.ee/files/ Rahapesu/ENG/rahapesu-aastaraamat-2017-eng.pdf?280ab771ac [aplūkots 05.03.2021.].

${ }^{9}$ National Integrity Agency. Pieejams: www.unodc.org/documents/treaties/UNCAC/WorkingGroups/ workinggroup4/2012-August-27-29/Responses_NVs_2012/20120417_Romania_English.pdf [aplūkots 05.03.2021.].

${ }^{10}$ Dix H. The Current Status of the Romanian National Integrity Agency. Pieejams: https://www.kas.de/ en/web/rlpsee/laenderberichte/detail/-/content/the-current-status-of-the-romanian-national-integrity-agencyl [aplūkots 05.03.2021.].

11 Sk.: Grigorov G., Kuzmanova N., Zarkov K., Galabov A. Forfeiture of Illegal Assets: Challenges and Perspectives of the Bulgarian approach. Sofia, 2014. Pieejams: http://www.confiscation.eu/site/wp-content/ uploads/2014/04/FORFEITURE-OF-ILLEGAL-ASSETS-CHALLENGES-AND-PERSPECTIVES-OFTHE-BULGARIAN-APPROACH.pdf [aplūkots 05.03.2021.]. 
atsavināšanu un iztiesāšanā darbojas kā puse. Tiesa var konfiscēt gan nelikumīgos aktīvus, gan to izmantošanā gūto peḷnu, tai skaitā - arī trešajai personai nodotos aktīvus, ja tā zinājusi par īpašuma nelikumīgo izcelsmi.

[9] No aplūkotajiem piemēriem tikai Igaunijā saskatāma iespējami noziedzīgi iegūtu līdzekḷu administratīvi procesuāla "ieskaitī̌šana valsts budžetā", ja to īpašnieks nav noskaidrots. Šāds process, kura piemērošana reālajā praksē nevarētu būt pārāk bieža, ir apsverama ideja. Savukārt pārējās valstīs pārvaldes iestāde administratīiā procesa kārtībā pārbauda personas mantiskā stāvokḷa neskaidru pieaugumu un rosina tiesā atsavināt nepamatoti gūto labumu. Turklāt Bulgārijā tā tomēr būtu uzskatāma par civilprocesuālo atsavināšanu.

\section{Konfiskācijas iespējas civilprocesa kārtībā}

[10] ANO Pretkorupcijas konvencija jau 2005. gadā ierosināja: "Dalībvalstis var izskatīt iespēju prasīt, lai likumpārkāpējs pierāda, ka iespējamie noziedzīgi iegūtie līdzekḷi, kas būtu konfiscējami, ir likumīgi iegūti - tādā mērā, kādā šī prasība atbilst to nacionālajiem normatīvo aktu pamatprincipiem, kā arī to tiesvedības un citām procedūrām." (31. panta 8. daḷa) Lìdzīgs priekšlikums ir arī FATF 40 rekomendāciju dokumentā kā 3. ieteikums, arī 2005. gada Varšavas konvencijā (3. panta 4. punkts). Šādu konfiskācijas iespēju iesaka arī Direktīva 2014/42/ES un Eiropas Parlamenta un ES Padomes 2014. gada 3. aprīla rezolūcija par nozieguma rīkiem un līdzekḷiem. Likumpārkāpējam pierādī̌̌anas pienākums izriet no sacīkstes principa, kas ir raksturīgs civilprocesam. Šeit vēlreiz jāuzsver - patiesam sacīkstes principam, kur abām pusēm ir vienādas pierādījumu gūšanas iespējas un vienādas tiesības iepazìties ar otras puses iesniegtajiem pierādijumiem.

Civiltiesiska atsavināšana vēsturiski vairāk raksturīga anglosakšu tiesību sistēmām (ASV, Kanāda, Apvienotā Karaliste, İrija, Austrālija, Dienvidāfrika), bet mūsdienās tā ir paredzēta arī Itālijas, Slovākijas, Grieḳijas, Albānijas, Slovēnijas, Ukrainas un Gruzijas likumos. Civilprocesuālā kārtībā var konfiscēt (atsavināt), gan pamatojoties uz esošu notiesājošu kriminālspriedumu, gan neatkarīgi no tā.

\section{Ar notiesājošu spriedumu}

[11] Gruzijas Civilprocesa kodeksā̄12 kopš 2005. gada ir $34 .{ }^{1}$ nodaḷa “Tiesvedỉba par tādu īpašumu konfiskāciju un nodošanu valstij, kas iegūti no reketa darbībām vai kas pieder kriminālās pasaules personām, cilvēku tirgotājiem, personām, kas veicinājuši narkotiku izplatību, vai kas notiesātas pēc Gruzijas Kriminālkodeksa 194. un/vai 331. ${ }^{1}$ panta”. Saskaṇā ar kodeksu atsavināšanas procedūru var uzsākt prokurors, iesniedzot tiesā iesniegumu, kurā lūgts konfiscēt nelegālas izcelsmes aktīvus, kas pieder personai (piemēram, kas notiesāta par korupciju vai legalizāciju) vai viņa ğimenes loceklim (radiniekam). Tādu prasījumu tiesā var iesniegt 10 gadu laikā pēc notiesāšanas. Tiesa lemj, vai aktīviem ir nelegāla izcelsme, un pēc tam attiecīgi - vai tie nav jāatdod kādai trešajai personai vai arī ir konfiscējami (dạ̄ā, kas ir nelegāli). Parasti prokurors, kas virza krimināllietu un identificē šādu nelegālas izcelsmes mantu, nodod materiālus citam prokuroram, kurš darbojas ar līdzekḷu piedziṇu. Prokurors uzsāk finanšu izmeklēšanu. Prasījumā tiesā

\footnotetext{
12 Civil Procedure Code of Georgia. Pieejams: https://matsne.gov.ge/en/document/download/29962/92/ en/pdf [aplūkots 05.03.2021.].
} 
prokurors pierāda, ka nevienam no atbildētājiem nebija tādi ienākumi, lai attiecīgajā periodā iegādātos tādus īpašumus. Atbildētāji savukārt sniedz pierādījumus par mantas iegādi. Mums šis process vairāk zināms pēc ECT sprieduma lietā "Gogitidze un citi pret Gruziju". ${ }^{13}$

[12] Ukrainā civilprocesuālo atsavināšanas kārtību ieviesa 2015. gadā. Civilprocesa kodeksa ${ }^{14}$ 3. sadaḷas 12. nodaļu sauc "Prasības izskatī̌sanas īpatnības nepamatotu aktīvu gadījumos un to atgūšana valsts ieņēmumos” (290.-292. pants). Saskaṇā ar kodeksu Specializētās korupcijas novēršanas prokuratūras prokurors 3 gadu laikā pēc notiesājoša sprieduma (tikai lietās pret valsts un pašvaldību amatpersonām korupcijas vai noziedzīgi iegūto līdzekḷu legalizācijas lietās, kā arī juridiskām personām, kas saistītas ar šo amatpersonu) var iesniegt prasību tiesā. Persona var iesniegt pierādījumus par mantas likumīgo iegūšanu.

\section{Bez notiesājoša sprieduma}

[13] Visai aptverošs likums un konfiskācijas iespējas ir Albānijā, taču šo regulējumu nopietni kritizē par nesamērīgu iejaukšanos cilvēktiesībās. ${ }^{15}$ No 2010. gada ir spēkā likums "Par organizētās noziedzības apkarošanu" (t. s. Antimafijas likums), kas kopā ar attiecīgām normām Civilprocesa likumā paredz iespēju konfiscèt to personu mantu, kuras tiek turētas aizdomās par smagu noziegumu (likumā dots izsmel̦ošs uzskaitījums) izdarī̌̌anu. Tāpat likumu var piemērot arī pret šo personu tuviniekiem un saistītajām juridiskajām personām. Ja ir aizdomas, ka mantai ir nelegāla izcelsme, prokurors un policija veic finanšu izmeklēšanu (pārbauda finanses, aktīvus, komercdarbību, profesionālo darbību, dzīvesveidu, ienākumu avotus). Prasību par konfiskāciju tiesā iesniedz prokurors. Materiālus izskata kriminālās justīcijas tiesa, bet civilprocesa kārtībā. Izmeklēšanas laikā lūgumu par aktīiu arestēšanu izlemj viens tiesnesis, bet prasību par konfiscēšanu - trīs tiesneši. Tiesai prasība jāizlemj 3 mēnešu laikā.

[14] Par samērā efektīviem var uzskatīt Slovēnijas likumus. ${ }^{16}$ Jau vēsturiski tur bija iespējama konfiskācija kriminālprocesa kārtībā, ja persona tika notiesāta. Taču šì kārtība ḷāva konfiscēt tikai pierādīto noziedzīgi iegūto mantu. Slovēnijas Republikas Konstitucionālā tiesa divas reizes (2002. gadā - spriedums lietā U-I-296/02 un 2015. gadā - spriedums lietā Up-6/14) atzina, ka jābūt pierādītai mantas noziedzīgajai izcelsmei. Kā vēlāk skaidroja Slovēnijas tieslietu ministre K. R. Longara, rodoties aizdomām par finanšu aktīvu iegūšanu noziedzīgu darbību rezultātā, ir jāuzsāk finanšu izmeklēšana, lai civilprocesa kārtībā varētu šos līdzekḷus

${ }^{13}$ Eiropas Cilvēktiesību tiesas 12.05.2015. spriedums lietā Gogitidzeandothers v. Georgia, pieteikums Nr. 36862/05. Pieejams: http://hudoc.echr.coe.int/fre?i=001-154398 [aplūkots 05.03.2021.]. Jāpiebilst, ka no konkrētās lietas materiāliem gan izriet, ka notiesājošs spriedums krimināllietā vēl nebija stājies spēkā, taču bija uzrādīta apsūdzība. Praktiski tas varētu būt apsūdzības raksts, kas dažās valstīs ir dokuments, ar kuru lietu nodod tiesai.

14 Civiljnij procesualjnij kodeks Ukraini. Pieejams: https://zakon.rada.gov.ua/laws/show/ru/1618-15\#n8248 [aplūkots 05.03.2021.].

15 Albanian Judicial Practice in the Interpretation and Implementation of Seizure of Crime Proceeds under the Anti-Mafia Law. Opinion of the Department of the Information Society and Action against Crime (DGHL), Council of Europe, prepared on the basis of the expertise by Pedro Perreira, Council of Europe Expert and Gent Ibrahimi, PACA Long Term Advisor. 2011. Pieejams: https://rm.coe.int/16806ec88e [aplūkots 05.03.2021.].

16 Disposal of Confiscated Assets in the EU Member States. Laws and Practices. Center for the Study of Democracy. 2014. Pieejams: https://www.files.ethz.ch/isn/185046/Disposal-of-confiscated-assets-report. pdf [aplūkots 05.03.2021.]. 
atsavināt. ${ }^{17}$ Tāpēc arī 2011. gadā tika pieṇemts Likums par nelegālas izcelsmes aktīvu atsavināšanu. Lai atsavinātu aktīvus, nav nepieciešama personas notiesāšana, taču ir jābūt pamatotām aizdomām koruptīva vai cita nozieguma (iespējamais sods virs 5 gadiem) izdarīšanā un jākonstatē šaubīgas izcelsmes īpašuma (aktīvi virs 50000 EUR) piederība. Lieta ir tikai par šo īpašumu (lieta in rem), un aktīvi tiek atzīti par nelikumīgiem, ja netiek pierādīts, ka iegūti no likumīgiem avotiem. Tātad aizdomu gadījumā tiek uzsākta finanšu izmeklēšana (ne ilgāk par 1 gadu), ko organizē prokurors, bet kā prasītājs uz tiesu tomēr iet specializētās prokuratūras prokurors. Prasību civilprocesa kārtībā tiesā iesniedz prokurors pret aktīvu īpašnieku kā atbildētāju. Prasītājam jāsniedz pierādījumi, kas radītu aizdomas par mantas nelikumīgo izcelsmi, kā arī par citiem apgalvojumiem.

[15] Tātad civilprocesuālā konfiskācija ir iespējama, lai atsavinātu nelikumīgus līdzekḷus. Proti, tiek pierādīts, ka personas īpašums neatbilst tās legālajiem ienākumiem, turklāt persona ir saistīta ar noteikta smaguma noziegumiem. Pie tam dažās valstīs ir pietiekami, ja ir pamatotas aizdomas par šāda nozieguma izdarǐšanu. Finanšu līdzekḷu izcelsmes noskaidrošanai tiek veikta finanšu izmeklēšana, kas nav kriminālprocesuāla (to regulē minētie speciālie likumi). Prasību civilprocesa kārtībā cel prokurors, un tas, škiet, ir radies ASV likumu un prakses ietekmē. Atbildētājam reālā sacīkstes procesā ir tiesības pierādīt mantas legālo izcelsmi.

\section{Kriminālprocesuālā konfiskācija}

[16] Pamatā visās valstīs noziedzīgi iegūtās mantas konfiskācija piemērojama, pamatojoties uz notiesājošu spriedumu (Igaunija, İrija, Grieḳija, Spānija, Itālija, Latvija, Austrija, Polija, Portugāle, Somija), taču pēc 2014. gada grozijumiem direktīvā vairākas valstis ir paredzējušas iespēju konfiscēt arī bez šāda sprieduma (Vācija, Īrija, Spānija, Kipra, Latvija, Malta, Portugāle, Somija, Zviedrija). Taču tas parasti ir ierobežots ar atrunām, piemēram, tikai tad, ja kriminālprocesu nevar turpināt sakarā ar aizdomās turētā vai apsūdzētā saslimšanu vai bēguḷošanu (Malta, Austrija) vai process jāizbeidz noilguma dēḷ (Zviedrija), vai likumpārkāpējs miris (Grieķija). Šādos gadījumos to piel̦auts veikt arī procesā in absentia (Beḷgijā, Igaunijā, Nìderlandē, Slovākijā).

[17] 2020. gadā Eiropas komisija izteica priekšlikumus ar aicinājumu paplašināt non-convicted konfiskācijas iespējamību, proti, rast iespēju konfiscēt no noziedzīgām darbībām iegūtu mantu arī tad, ja persona par šìm darbībām vēl nav notiesāta (izstrādāts speciāls darba dokuments "Uz spriedumu nebalstītu konfiskācijas pasākumu analīze"18). Lai gan valstis pamatā balstās uz klasisko konfiskāciju, praksē parādās arī tādi procesi, kuros nav notiesājoša sprieduma, bet arī cilvēku pamattiesības netiekot pārkāptas. Tomēr pašlaik komisija vēl nevarot sniegt pamatotu novērtējumu. ${ }^{19}$

17 Longar K. R. Analysis of the Legal Aspects of Illegal Asset Recovery in Slovenia. Pieejams: https://www.fvv. um.si/rv/arhiv/2018-4/03_RejecLongar_rV_2018-4.pdf [aplūkots 05.03.2021.].

18 Analysis of non-conviction based confiscation measures in the European Union. Commission staff working document. 2019. Pieejams: https://ec.europa.eu/transparency/regdoc/rep/10102/2019/EN/SWD2019-1050-F1-EN-MAIN-PART-1.PDF [aplūkots 05.03.2021.].

19 Asset recovery and confiscation: Ensuring that crime does not pay. Report from the Commission to the European Parliament and the Council. 2020. Pieejams: https:/ec.europa.eu/home-affairs/sites/ default/files/what-we-do/policies/european-agenda-security/20200602_com-2020-217-commission-report_en.pdf [aplūkots 05.03.2021.]. 
[18] Arī Igaunija 2016. gadā (spēkā no 2017. gada) veica grozījumus Kriminālprocesa kodeksā ${ }^{20}$, ieviešot jaunu $16 .^{1}$ nodal̦u, kas nosaka noziedzīga nodarījuma rīku, tiešo objektu un noziedzīgi iegūtā īpašuma konfiskācijas procedūru. Tomēr šîs normas paredz, ka ir jābūt notiesājošam spriedumam, kurš var arī vēl nebūt stājies spēkā, lai prokurors varētu uzsākt jaunu procesu par noziedzīgi iegūtās mantas konfiskāciju un iesniegt prasījumu tiesai.

[19] Īpaši aplūkojams ir jautājums par paplašinātās konfiskācijas iespējām. Starptautiskajos dokumentos šis jēdziens parādījās 2005. gadā (pēc būtības - arī Latvijas KPL), un šobrīd tā ir atḷauta gandrīz visās ES valstīs (Beḷgija, Čehija, Grieķija, Igaunija, Īrija, Itālija, Kipra, Latvija, Luksemburga, Polija, Portugāle, Spānija, Ungārija, Zviedrija). Paplašinātā konfiskācija paredz tiesības konfiscēt notiesātajam piederošo mantu, ja (1) konkrētā noziedzīgā darbība var dot ekonomisku labumu un (2) lietas apstāḳ̣i norāda, ka īpašums varētu būt iegūts no šīs noziedzīgās rīcības. Šì konfiskācija var ietvert arī legālos ienākumus. ${ }^{21}$ Te raksturīgi tas, ka īpašuma noziedzīgā izcelsme tiek prezumēta.

[20] Tāpat jāievēro, ka paplašinātās konfiskācijas gadījumos valstīs ir atšķirīgi pierādī̌̌anas standarti. Piemēram, Austrijā atḷauts, ja ir "saprātīgi pieṇemams", ka īpašums radies prettiesiskas rīcības rezultātā, Kiprā un Nīderlandē - tiesa "pieṇem”, ka aktīvi radušies no nelikumīgām darbībām, Čehija - tiesa "apsver", Spānijā - tiesa lemj, pamatojoties uz objektīviem pierādījumiem, Beḷgijā - nopietnas un konkrētas norādes, Zviedrijā - vairāk ticami, Rumānijā - tiesai jābūt pārliecinātai.

[21] Pamatā visur kā kritērijs konfiskācijas procesa uzsākšanai ir būtiskas atškirīibas starp skartās personas likumīgajiem ienākumiem un viṇa dzìvesveidu jeb finansiālo stāvokli. Dažkārt tiek noteikta šīs "neskaidrās summas" zemākā robeža, piemēram, Lietuvā tie ir 12500 EUR, Polijā 47000 EUR, vai šai atšķirībai jābūt neproporcionālai, piemēram, Bulgārijā - 76000 EUR, Slovēnijā 50000 EUR, Slovākijā - 1500 minimālās algas. Tāpat būtiski ir tas, ka pamatā visas valstis ierobežo termiņus, kādos analizējamie aktīvi varētu tikt uzskatīti par noziedzīgi iegūtiem. Piemēram, Beḷgijā, Portugālē Rumānijā, Ungārijā tie ir 5 gadi pirms apsūdzības izvirzī̌sanas, Kiprā - 6 gadi, Bulgārijā - 10 gadi, bet Čehijā, Lietuvā, Polijā - 5 gadi pirms nodarījuma izdarīšanas, Nīderlandē - 6 gadi. ${ }^{22}$ Latvijā nav noteikts nedz būtiskuma apmērs, nedz laika posms pagātnē, kas nesaprātīga tiesību normas piemērotāja gadījumā var radīt gan netaisnīgu spriedumu, gan cilvēktiesību nepamatotu aizskārumu. Piemērs nav tālu jāmeklē - to pierāda Latvijas zaudējums ECT 2020. gada 11. jūnija spriedumā lietā "Markus pret Latviju". ${ }^{23}$

${ }^{20}$ Code of Criminal Procedure of Estonia. Pieejams: https://www.legislationline.org/download/id/8697/file/ Code_Criminal_Procedure_2003_am2020_en.pdf [aplūkots 05.03.2021.].

21 Asset recovery and confiscation: Ensuring that crime does not pay. Report from the Commission to the European Parliament and the Council. 2020. Pieejams: https:/ec.europa.eu/home-affairs/sites/ default/files/what-we-do/policies/european-agenda-security/20200602_com-2020-217-commission-report_en.pdf [aplūkots 05.03.2021.].

22 Ibid., p. 8.

${ }^{23}$ Eiropas Cilvēktiesību tiesas 11.06.2020. spriedums lietā Markus v. Latvia, pieteikums Nr. 17483/10. Pieejams: https://www.stradalex.com/en/sl_src_publ_jur_int/document/echr_17483-10 [aplūkots 05.03.2021.]. 


\section{Kopsavilkums}

1. Latvijā veiksmīgi darbojas kriminālprocesuālā konfiskācija. Turklāt kopš 2005. gada ir iespējama gan paplašinātā konfiskācija, gan konfiskācija bez notiesājošā spieduma (non-convicted konfiskācija). Tomēr vairāki šo konfiskāciju piemērošanas teorētiskie aspekti, bet it īpaši - praktiskā realizācija, rada šaubas par tiesību uz taisnīgu tiesu nodrošināšanu.

2. Paplašinātās konfiskācijas piemērošanai Latvijā būtu jānosaka mantiskā stāvokḷa un legālo ienākumu "acīmredzamā nesamērīgā" atšķirības līmeṇa minimālā robeža. Tāpat par netaisnīgu būtu atzīstama tāda īpašuma konfiskācija, kas personas valdījumā ir nonācis vairāk nekā 5 gadus pirms noziedzīgo nodarījumu izdarīšanas.

3. Non-convicted (bez notiesājošā sprieduma) konfiskācija kriminālprocesā būtu pię̧aujama tikai tajā apmērā, kādā tas bija paredzēts KPL sākotnējā redakcijā, proti, kad (1) ir pietiekams pierādijumu kopums ārpus saprātīgām šaubām, ka konkrētā manta ir noziedzīgi iegūta, un (2) šādas izṇemtas un arestētas mantas ilgstoša uzglabāšana līdz galīgajam nolēmumam radīs nesamērīgus izdevumus. Šajā procesā var izmantot kriminālprocesā gūtos pierādījumus, taču nodrošinot ar mantu saistītajai personai tiesības piedalīties taisnīgā tiesas procesā, tai skaitā tiesības iepazīties ar otras puses pierādījumiem.

4. Visos gadījumos, kad konfiskācijai vai mantas atsavināšanai valsts labā būtu interese pakḷaut neskaidras izcelsmes mantu, ir jāuzsāk finanšu izmeklēšana. Turklāt tā jāveic specializētai struktūrai, jo noziedzīgo nodarījumu izmeklētājiem un prokuroriem primārais uzdevums ir noziegumu atklāšana, kuras rezultāti nebūt nav spīdoši. Tā ir prasība sabiedrības drošības interesēs. Savukārt finanšu izmeklēšana un tai sekojošā prasības iesniegšana tiesā civilprocesa kārtībā būtu juridiski korekta, jo reāla sacīkstes principa ietvaros procesā tiktu nodrošinātas gan procesuālo pušu vienlīdzīgās tiesības, gan taisnīgs tiesas process. 